\title{
Mantıksal Davranıșçılık
}

\section{Logical Behaviorism}

\author{
NORMAN MALCOLM \\ Çeviren / Translated by \\ İLYAS ALTUNER \\ Iğder University
}

\begin{abstract}
The paper deals exclusively with the doctrine called 'Logical Behaviorism'. Although this position does not vogue it enjoyed in the I930s and I940s, it will always possess a compelling attraction for anyone who is perplexed by the psychological concepts, who has become aware of worthlessness of an appeal to introspection as an account of how we learn those concepts, and he has no inclination to identify mind with brain. There, of course, are other forms of behaviorism, and of reductionism, which is might have discussed in this essay. From Carnap's point of views, it will serve its purpose if it leads the reader into the writings of Wittgenstein, who is easily the most important in the philosophy of mind. It should not be expected, however, that the reflections and observations of his Philosophical Investigations or his Zettel will somehow add up to another theory. To use his metaphor, philosophical work of the right sort merely unties knots in our understanding.

Keywords: Logical behaviorism, Wittgenstein, Carnap, asymmetry, attitudes and behaviors.
\end{abstract}




\section{I. İç Gözlemin Reddi}

Burada konu edilen davranışçılık ne bir deneysel inceleme programı ne de "uyaran” ve "tepki”nin görgül yasalarla bağlantılı olduğu öğretidir. O “düșünce, öfke, yönelim” gibi zihinsel terimlerin anlamının meydana gelen bedensel davranıs, ve fiziksel koșullar açısından tümüyle açıklanabileceği görüșüdür. Rudolf Carnap'ın bir keresinde söz ettiği gibi, "psikolojinin bütün tümceleri fiziksel olușumları, yani insanlar ve diğer canlıların fiziksel davranışını betimlediği” savıdır (Carnap, I959: I65). Bizim savımız, böylelikle, her psikolojik kavram (yani açıklama) için bir tanım olușturulabileceğini ifade eder, ki ister doğrudan ister dolaylı olsun o kavramı fiziksel kavramdan türetir (Carnap, 1959: 167). Başka kimseler için birinin zihinsel yüklemlerinin özniteliklerine bașvurulduğu gibi, bu görüș, "bașka zihinlerle ilgili tekil bir tümcenin daima belli bir fiziksel tümce kadar benzer içeriğe sahip" olduğu görüșüdür. "Bașka zihinlerle ilgili bir tümce, söz konusu kișinin bedeninin belli bir türün fiziksel durumu hakkında olduğunu ifade eder." (Carnap, ı959: I75). Benzer çözümleme, "bir fiziksel yorum için duygusal engeller oldukça önemli olmasına rağmen", birinin bașkasına zihinsel yüklemler hakkındaki yüklemeleri için de savunulur (Carnap, I959: I9I). Biri hakkında böyle tümcelerin fiziksel olmayan (bir “deneyim-içeriğii" veya "bilinç verisi”) bir șeye gönderimde bulunmadığı șeklindeki karșıt görüș, o tümcelerin yalnızca onları dile getiren kimse için anlamlı olduğu sonucuna götürür (Carnap, I959: 192). Kısacası, mantıksal davranışçılık, "ya bașka zihinler, ya birinin zihninin geçmiș bir koșulu, ya birinin zihninin șimdiki koșulu hakkında somut tümceler, ya da sonuçta genel tümceler olan sözde psikolojik tümcelerin daima fiziksel bir dile, yani fiziksel oluşumlar ve fiziksel durumlarla ilgili tümcelere çevrilebilir oldukları"nı savunur (Carnap, 1959: 197).

$\mathrm{Bu}$ öğreti, zihinsel kavramların iç gözlemden edinildiği biçimindeki Lockeçu görüșün doğal bir rakibidir. Davranışçı filozoflar, zihinsel kavramların gözlemlenebilir davranıștan salt ayrılmasının kesinlikle solipsizme götürdüğünü anladılar (Krș. Malcolm, I964: I48-9). Elinizdeki incelemede, birinin zihinsel kavramlarının "onun kendi durumu”ndan türetildiği varsayımının bir kimsenin kendi durumunda bile anlamsızlığa götürdüğü yönünde bașka bir görüș sunuldu.

Mantıksal davranışçılık zihinsel kavramların iç gözlemsel kaynağı ko- 
nusunda Lockeçu kurama karşı çıksamasına karșın, bașka bir yönden yanılgı içindedir. Yanlıș olan șeyin onunla açıklanması, felsefenin en kafa tutucu problemlerinden biridir. İzleyen kısımlarda mantıksal davranıșçılığın iki temel eleștirisi öne sürülecektir.

\section{Zihinsel Kavramlardaki Bakıșımsızlık}

Davranıșçılı̆̆ın en inandırıcı yanı, onun, birinin kendisinden bașka kimselerin düșünce ve duygularıyla ilgili tümcelerinin anlamı hakkındaki açıklamasıdır. Birine Robinson'ın hastalığı hissettiği yönündeki ifadem, Robinson'ın davranıșı, eylemleri ve söylemleriyle desteklenir ya da çürütülür. Bunun bir doğrulama yöntemi olduğunu fark etmeyi bașaramasaydım, o böyle bir ifadenin anlamını anlamak için bir eksiklik olurdu. (Birinci Bölüm'de ișlenen) anlayıș, ki içsel gösterimsel tanım ve özel nesne bașka zihinler hakkındaki ifadeleri anlamamızda hiçbir rol oynayamaz ve bu anlama birinin kendi durumuyla ilgili bir analoji üzerinde bulunamaz, bizi o ifadelerin anlamının tamamen onların gözlenebilir davranıșına gönderim yoluyla çıkarıldığı sonucuna zorladığı görülür.

Davranışçı filozoflar, birine ve bașka kimselere yüklenen zihinsel yüklemlerin doğrulama bakımından bakıșımlı olacağı șeklindeki doğal varsayıma ulaștılar. Carnap, "Ben heyecanlıyım” ifademin, "rasyonel dayanak"ını "Ellerimin titrediğini görüyorum", "Sesimin titrediğini ișitiyorum" ve sair tümceler tarafından açıklanacak gözlemlerden edinmediğini düşündü (Carnap, I959: I9I). Ancak bu tümcelerin kullanımını iyice düșünme, bunun böyle olmadığını açığa çıkarır. Benim heyecanlı olduğuma inanmadısanız, ellerimin nasıl titrediğini dikkatle gözleterek sizi inand1rabilirdim. Ancak heyecanlı olduğumu böyle bir gözlemle kendime inandırmaya kalkıșmam; eğer kalkıșsaydım, bu çok normal olmayan bir durum olurdu. "Benimle görüșmeyi reddettiği için ona kızgınım” dersem, ifadem normalde fiziksel öfke açıklamalarım hakkındaki gözlemime dayanmaz. Öfkeli olduğumu ne yüzümün kızarık veya yumruğumun sıkılmıș olduğunu gördügüum ne de çı̆̆lı̆̆ımı duyduğum için söylerim. Normal durumda onun bir șey hakkında gözlemin temelinde olduğunu söylemiyorum.

Burada can sıkıcı bir sorun vardır, yani, zihinsel terimlerin dilini kendimize uygulamayı nasıl öğreniriz? "Ona kızgınım” veya "On buçukta ayrılmayı düșünüyorum” sözlerini ne zaman söyleyeceğimi nasıl öğrenirim? 
Davranışçı B.F. Skinner bu konudaki birtakım kafa karışıklıklarını açıkladı. Konușmacının kendi yönelimleri hakkındaki ifadeleri, "yalnızca konușmacı için erișilebilir olduğu görünen işlerin durumlarını betimler. Sözlü ortaklık bu türün yanıtlarını nasıl saptayabilir?” Skinner'ın varsayımı, ilkin, bir kimsenin doğru genel davranıș sergiliyorken, bu dili kullandığ1nın düșünüldüğü, daha sonra ise (“özel uyaranlar” denilen) içsel fiziksel değişkenlerin "genel göstergeler" ile ilgili olduğu yönündedir. Ardından o kişi, genel göstergeler olmaksızın varolduklarında bu "özel uyaranlar”a karșllı verir. Skinner, "Eve gitmek üzereydim" tümcesinin "belki 'kendine özgü biçimde eve gitmemden önce ya da onunla aynı zamanda olan olayları gözlemledim' tümcesinin eșdeğeri sayılabilir” olmasını önerir (Skinner, 1953: 262).

Aslında kișiler, yönelimlerinin bildirgelerini bedenlerindeki olayların farkında olușlarına dayandırmazlar (Malcolm, I964: 15I-2). Hiç kimse bu içsel fiziksel olușumların "kendine özgü biçimde" eve gitmemden, imza atmamdan, telefon etmemden veya yaparken kendime bildirebildiğim sayısız olayların birinden önce ya da onunla aynı zamanda oluștuğu varsayılan șeyler olduğunu bilmez. Skinner'ın varsayımı, gerçeklerden çok uzaktır. O, yalnızca bir konușmacının amaçladığı, düşündüğü veya istediği șeyle ilgili ifadelerinin konușmacının bir șey hakkındaki gözlemine dayanması gerektiği șeklindeki yanlıș varsayımından üretilen kuramsal bir problem çözümüdür.

$\mathrm{Bu}$, benim duygu, düşünce ya da yönelimlerimle ilgili ifadelerimi bedensel eylemlere dayandırmadı̆̆ımı söylemek için yetersiz bir ifadedir. Eğer böyle yapmıș olsay $d \mathrm{~m}$, kimse beni anlamazdı. "Paltomu giyiyorum, çünkü açıkça eve gitmeye niyetim var” dediğimi varsayın. Bu ifade şakacıktan söylenebilirdi. Ancak ciddî olduğu izlenimini verseydim, bașkaları bana tuhaf bir biçimde bakardı. Eve gitmeye yöneleceksem, davranıșımın gözlemine bașvurmaksızın bunu hemenduyurabilmeliyim. Gerçekten, eğer ifadem doğruca kendimin bu tür gözlemine dayansaydı, bir yönelim açıklaması olmazdı.

Bașkası hakkında "Sızlanmasından ve iki büklüm durmasından dolayı onun karnının ağrıdı̆̆ını biliyorum” diyebilirim. Ancak duyum kavramının gülünç bir yanlış anlamasını açığa çıkarmaksızın kendi açımdan bunu söyleyemem. Bașkasıyla ilgili "Yüzüne bakarak onun șașkın olduğunu söyle- 
yebilirim" ifadesini söyleyebilirim; ancak kendimle ilgili bunu söylemek, bir yerde bir yanlıș anlama olduğunu gösterir.

$\mathrm{Bu}$, pek çok zihinsel kavramın temel bir özelliğidir, ki onların bir kimse tarafından birisine uygulanmasıyla bașka kimselere uygulanması arasında köklü bir uyumsuzluk vardır. Güçlü bir yatkınlıkla (örneğin așk veya yiğitlik) ilgili olan zihinsel kavramların bu özelliği yoktur ya da en azından bakıșımsızlık bu denli keskin değildir. Ancak büyük bir zihinsel kavramlar dizisi için keskindir. Bașka birinin hasta hissettiğini, güneșin dıșına çıkmak istediğini veya eve gitmeye yöneldiğini ileri sürmek için kanıt bulmayı umuyorum. Eğer kanıt yoksa, bu savları ileri sürmeye hakkım yok. Ancak kendi durumumda kanıta sahip olmayı ummak bir yana, kanıtım bile var. Kendi duygu ve yönelimlerim hakkında böyle ifadelere yer vermeye "hakk"ım olup olmadığını söylemek yersiz olur. Genel görüș șu șekilde konulabilir: Pek çok zihinsel kavram tarafımızdan bașka insanlara davranıs, ölçütlerine yani yüz ifadesi, söylem veya fiziksel eylem değișimine dayalı olarak uygulanır. Ancak onları bu ilkeye göre kendimize uygulamayız. Böylece mantıksal davranışçılık onların kullanımının bir kısmının yanlıs, bir değerini verir.

Bir davranışçı "Hasta hissediyorum" veya "Șimdi ayrılacağım” gibi sözlerin gerçekten ifadeler, bildirimler ya da betimlemeler olmadığını ve hiçbir bilişsel içerikleri bulunmadı̆̆ını sürdürerek bu sonuçtan kaçınmaya çalıșabilir. Onlar, ișlevi bașka kimselerden yanıt almak olan ünlemler, uyarılar ya da imlerdir. Onlar, psikolojik tümcelerin bilișsel içeriğinin bir davranışçı çözümlemeyle verilebileceği tezinin karşı örneği değildir.

Buna koșullara bağlı olarak "Hasta hissediyorum” sözünün yalnızca bir ünlem olmayıp aynı zamanda bir bildirim olabileceği yanıtı verilmelidir. Kendinizle ilgili bir șey söylediğinizde, söyleminiz pek çok farklı bașlık altına girebilir. Eğer "Hemen ayrılacağım” derseniz, birkaç olanaktan söz etmek için ya (size davranılma tarzı için) gücenmeyi anlatıyor, ya (davranıs, karșısında) kararınızı belirtiyor, ya bir soruya yanıt veriyor, ya çekiciliği reddediyor, ya da bir çözümü yeniden doğruluyorsunuzdur. O söylemi gerçekleștirerek yaptığınız șey, konuștuğunuz kișiye, ortamın ne olduğunun (ister bir mahkeme durușması, ister psikolojik bir deney, isterse bir aile kahvaltısı olsun) önceden söylendiği șeyin bir konusudur (Krș. Wittgenstein, I953: I87-8). Basit geniș zaman bildiren birinci tekil kiși hakkındaki zihinsel 
terimlerin kullanıldığı tümcelerin ifade veya bildirimler yapmaya ya da betimlemeler vermeye asla alıșık olmadığı yargısı açıkça yanlıștır. Ancak bu șekilde kullanıldıklarında, konușmacı normalde davranıș ölçütüne güvenmez. Bu söylemlerin bir "bilișsel içerik"e sahip olmadığı savına gelince, bu deyimin anlamının, tanınabilirlik açısından herhangi bir önemli savın yapılmadığını kabul etmek için oldukça belirsiz olduğunun söylenmesi gerekecektir.

\section{Zihinsel Terimlerin İki Anlamını Kastetme Olarak Bakıșımsızlık}

Bir filozof zihinsel terimlerin biri tarafından bașkalarına veya birine uygulanması konusundaki ayrımı algıladı̆̆ında, solipsizm tehlikesini yeniden hissedebilir. O șöyle düșünebilir: "Birisi, bu terimleri bașkalarına uygulama konusunda, davranıs, ölçütünü kullanmayı öğrenmesi gerekirken, bir kimseye uygulama konusunda davranıș ölçütünü kullanmamayı öğrenmelidir. Bir yandan birinin ifadelerinin anlamı davranışla bağlantılıyken, diğer yandan bağlantılı değildir. Birisi, iki durumda da aynı tür șeyi söylüyor olamaz. Onların bașkalarına uygulanması konusunda, bir kimsenin ifadeleri aslında bedenlerin davranıșı hakkında olması gerekir. Ancak zihinsel terimler bir kișiye uygulanırken, birisi davranıșa gönderim yapıyor olamaz. Öyleyse birisi, bașkasının bir kimseyle aynı anlamda öfkeli olduğunu kastedemez. Son durumda "öfke" doğrudan öfke anlamına gelirken, diğer durumda davranış anlamına gelir.

Kendime uyguladığım bir șey ve size uyguladığım bir șey olarak iki ağrı kavramına sahip olduğum doğru değildir. "Ağrı” terimini (ölçüsüz olarak) kendime ve (ölçülü olarak) size olmak üzere iki tür uygulayıșım, biri diğerinden soyutlanmıs, değildir. Bu, birinin her iki uygulama türünü de iyice öğrenme yanlıșlığının, bizi onun sözcüğü anlamadığını söylemeye götüreceği olgusundan anlaşılabilir. Eğer onun bașkalarının ağrı hissettiği yargısı uygun ölçütü çokça boș vermișse, onun ağrı hissettiğine dair "tanıklık" etmesine güvenmememiz gerekir. Benzer biçimde, eğer o kimse ağrıyı kendi davranıșının temelindeki kendisine bağlamıșsa, hatta onun bașkalarına dair yargıları doğru olsa ve normal ölçüte dayansa bile, sözcügün kastettiği șeyin tuhaf bir yanlıș anlayıșına sahip olduğunu düșünmemiz gerekir.

Ayrıca, zihinsel terimlerin benim tarafımdan bana uygulanmasını1 
benim davranıșımla bağlantısız olduğu, doğru olmaktan uzaktır. Wittgenstein'ın değindiği gibi, ağrı içinde olduğumu ya da davranıșım hakkındaki gözlemimden kendime șunu dediğimi söyleyemem: “Ancak bu șey, yalnızca bu tarz davranmam nedeniyle bir anlam ifade eder." (Wittgenstein, I953: par. 357). Yine șunu diyemem: "Birisinin kendisine bir șey söylemesi için ölçütümüz, bize anlattığı șey ve davranıșının geri kalanıdır; ve yalnızca, eğer sözcüklerin olağan anlamında konuşabiliyorsa, birinin kendisiyle konuştuğunu söyleriz. Bunu ne papağan ne de gramofon için söyleriz." (Wittgenstein, I953: par. 344)

O șekildeki davranıșım nedeniyle, önceki deneyimlerim bunu istiyorum, sersem bissediyorum, o nesneye bakıyorum, bir șeyi bıraktı̆̆ım yeri battrlıorum ve benzeri șeyleri söyleme konusunda beni yüreklendirdi. Davranıșlarım ve söylemlerim arasındaki uygun bağlantılara dayanarak, bașkaları benim konușmayı öğrendiğim yargısında bulundular. Șimdi bir gün beklenmedik șekilde șöyle bağırdığımı varsayalım: “Az önce kendime birtakım sözler söyledim, yüksek sesle değil ama sessizce!” Benim değinim, başkaları tarafından kendime sessizce bir șeyler söylememin bir ölçütü olarak ele alınacaktır. Ancak benim değinime, normal insan davranıșıyla ilgili önceki geçmișim nedeniyle bu önem verilebilir. Ĕğer bu arkaplan ortadan kaldırılırsa, benden gelen sesler konușma olmaz. Bu ise, Wittgenstein'ın șu aforizmasının anlamıdır: "Bir aslan konușabilseydi, onu anlayamazdik." (Wittgenstein, I953: 223).

Ölçütleri dilbilimsel olmayan zihinsel fenomenler, sözgelimi kimi ağrı veya korku biçimleri vardır. Böylece bir kedi veya köpeğin ağrı içinde veya korkmuș olduğunu söyleyebiliriz. Ölçütleri başlıca olarak dilbilim olan pek çok fenomen vardır. "Sahibinden korkan bir köpeğin onu ısıracağını söylediğimiz halde, sahibinden korkan belli bir köpeğin yarın sahibini ısıracağını söylemeyiz. Niçin değil?” (Wittgenstein, ı953: par. 650). Yanıt, yarınki bir olaydan korkmanın dilden bağımsız olarak varolmadığıdır. Bu korkuya sahip olsun ya da olmasın, dilsiz bir varlıktan söz etmenin anlamı yoktur. Dil, böyle bir korkunun varlığının ölçütünü verir.

Bașkaları tarafından zihinsel terimlerin bana uygulanmasında kullanılan ölçütler, kimi zaman benim dilbilimsel olmayan davranıșımı içerirken, kimi zaman dilbilimsel davranıșımı yani dediğim șeyi içerir. Ancak normal bir insanın özelliği olan eylemlerimin ve tepkilerimin geçmiș bir tarihine 
sahip olmam nedeniyle yalnızca ikincisi bu ölçütleri sağlayabilir.

Basit geniș zaman bildiren birinci tekil kiși hakkındaki psikolojik tümceler, normalde ölçütlere dayanmazlar, ancak onların ikinci ve üçüncü kișileri benzer ölçütlere dayanırlar. İki ifade kategorisi, doğrulamayla ilgili olarak bakıșımsız oldukları halde, aralarında mantıksal eșitlik olduğu sürece anlamca bağlantısız olamazlar. Sözgelimi, "Korkuyorum” demekle olușturduğum ifade, ancak ve ancak bașka birinin benim hakkımda "O korkuyor” diyerek olușturduğu ifade doğruysa, doğru olacaktır. Eğer bu üçüncü kiși ifadesinin doğruluğu veya yanlıșlığının bir ölçütü yoksa, doğruluk ve yanlıșlığın o șey için hiçbir uygulaması olmaz. Ama o zaman, birinci ve üçüncü kiși ifadeleri gerçeklik değeri konusunda mantıksal olarak eșit olduğu sürece, hiçbiri birinci kiși ifadesine uygulanmaya sahip olmaz. Böylelikle benim "Korkuyorum” sözünü söyleyerek bir șeyi doğru veya yanlıs, söylememin olanağı, "O Korkuyor” ifadesinin doğruluğu için davranıșsal ölçütlerin varlığına bağlıdır. Birinci kiși söylemleri ve o söylemlerin ikinci ve üçüncü kiși benzerleri, farklı yollarla, benzer davranıșsal ölçütlere bağlı olmaları nedeniyle anlamca bağlantılıdırlar. Bu bağlantı, benim için ayrı ve başka kimseler için ayrı olan farklı ağrı veya korku kavramlarına sahip olduğumun doğru olmasını engeller.

\section{4. İnsanlara Karși Tutumlar}

"Ona karșı tutumum, bir ruha karșı tutumdur. Onun bir ruha sahip olduğu kanısında değilim.” (Wittgenstein, I953: I78). Wittgenstein'ın bu değinisi, davranıșçılığa dair ikinci eleștirimizin bașlangıcını olușturur. Șimdi ilk olarak bir "tutum” kavramı geliștirelim. Wittgenstein, bazen fotoğraf ve resimlere baktığımız bir tarzda dikkatimize seslenir. Gülümseyen bir arkadașın fotoğrafına geri gülümseriz ya da kendimizi resim çerçevesinden gözetleyen acımasız bakıș tarafından azarlanmıș ve utandırılmıș hissederiz. Hatta sanki kișinin kendisiyle konușuyormuș gibi bir fotoğrafla da konuşabiliriz. Bu fenomeni șöyle diyerek betimleyebiliriz: "Duvarımızda asılı fotoğrafa, resme doğrudan orada resmedilmiș bir nesne (insan, manzara ve sair) olarak bakar1z." (Wittgenstein, 1953: 205). Kimi zamanlarda bu tutuma bașka zamanlarda olduğundan daha çok sahip oluruz; resimden gelen bakıșı sürekli hissetmeyiz. Ve kimi fotoğraflara karșı tutuma bașka fotoğraflardan daha çok sahip oluruz. 
Buna karșın, en ilginç olan șeyse, bir kișinin resmini bir kişi olarak hiç görmemiș birini düșlemektir. Wittgenstein șöyle der: "Böyle resimlerle bu tür bir ilișkisi olmayan insanları kolayca düșleyebiliriz. Sözgelimi her kim ise, renksiz bir yüz, hatta belki de kabaca onlara vurulan oranda azaltılan bir yüzleri olması nedeniyle fotoğraflar tarafından atılacaktır." (Wittgenstein, I953: 205; krș. par. 524).

Bu örnek, yașayan insanları algıladı̆̆ımız tarzdan olușan kiși kavramımızın bir boyutu olduğu düșüncesine yol hazırlamaya yardımcı olabilir. Temel problem, yașayan insanlara karșı tutumu herhangi bir karmașık organizma veya mekanizmaya karșı tutumundan farklı olan bir insan bulunabileceği düșüncesine bir anlam verip veremeyeceğimizdir.

Șimdi (kendisine Petersen denilen) birini düșünelim, ki bu adam tamamen bir insanın öfkeli veya ağrı içinde olduğunu ya da zihinsel yüklemlerin dayanağıyla falan filan ve sair șeylere inandığını söylemenin olağan ölçütüyle tanınan biri olsun. Bu kiși ruh hâlini, duyguları ve düșünceleri bașka birinin yaptığı kadar iyi ayırt edebilir. O gücenmiș, alıngan ve morali bozuk bir insandan beklenen șeyin ne olduğunu bilir. Petersen, çeșitli zihinsel ifadelerin bașka insanlara yüklenmesinin veya yüklenmemesinin ne içerdiğini bilir. Petersen ayrıca kendi düșüncelerini, isteklerini ve duygularını da normal yollarla açıklar. Petersen, betimlendiği kadarıyla, bizim dayanağımız gibidir. En azından Petersen’in "bir kiși kavramı”na sahip olup olmadığını kușkulu yapan bu betimlemeye bir șey eklenebilir mi?

Amacım, mantıksal davranışçılığı sırf kuramsal bir davranışçı değil ama, dediğimiz gibi, içgüdüsel veya doğal bir davranışçı olan bir insan düșleyerek oldukça ciddî ele almaya çalıșmaktır. O, günlük yașamda, mantıksal davranışçılığın bakılması gerektiğini dolaylı anlattığı gibi bașka kișilere bakacaktır. Bu ne gibi olabilir? Davranıșçılığa göre, "bașka zihinlere ilișkin tekil bir tümce, daima belirli bir fiziksel tümce gibi aynı içeriğe sahiptir" (Carnap, I959: 175). Bunun bütünüyle genel bir öğreti olduğu anımsanmalıdır. O, insanlara dair zihinsel terimler içeren ber betimlemenin bir salt fiziksel betimleme, yani hiçbir zihinsel terim içermeyen bir betimleme tarafından değiștirilebileceği yönünde sezdirime sahiptir. Carnap'ın dediği gibi, "psikoloji, fiziğin bir dalıdır" (Carnap, 1959: 197). Fiziksel betimlemeler temel betimleme formu gibi düșünülürler. Birisi fiziksel durumlar ve hareketlerin betimlemelerinden, mantıksal yapılar ya da fizik 
yasalarına dayalı çıkarımlar açısından, zihinsel terimlere (zihinsel betimlemeler) gidebilir. Yine bir kimse, çevrilebilirlik ilișkisi bakıșımlı olduğu sürece bașka bir yöne, zihinsel betimlemelerden fiziksel betimlemelere gidebilir. Davranışçılık bu eșitliğin fiziksel yanını daha köklü ve zihinsel yönünü de türetilmiș olarak düșünür. Mantıksal davranışçlığın bakıș açısı, aşağıdaki parçada açıkça ifade edilir:

Kendi konușma hareketleri uygun koșullar altında özellikle bilgilendirici olmasına karșin, deneyimsel bir öznenin ifadeleri, ilke olarak, istençli ya da istençsiz hareketlerinden farklı olarak yorumlanmaz. Yine biçimlendirici uygun koșullar altında genel tümcelerin yapılıșı konusunda daha değerli olabilmesine karșın, ilke olarak, konușma organlarının ve deneysel bir öznenin bedeninin diğer parçalarının hareketleri bașka bir hayvanın hareketlerinden farklı yorumlanmaz. Uygun koșullar altında hayvanların hareketleri bir voltmetrenin yaptığından çok daha fazla yolla bilimsel amaçlara yardımcı olabildiği hâlde, hayvanların hareketleri yine ilkece bir voltmetre hakkında onlardan farklı olarak yorumlanmaz. Son olarak, biçimlendirici, ikincisinin yaptığından bașka oluşumlara çıkarımlar yapmak için çok daha elverișli durumlar önermesine rağmen, bir voltmetrenin hareketi, ilkece bir yağmur damlasının hareketinden farklı yorumlanmaz. Bütün bu durumlarda konu aslında aynıdır: Belirli bir fiziksel tümceden, nedensel bir argüman yoluyla, sözgelimi genel fiziksel formüller yani sözde doğal yasalar yardımıyla bașka tümceler ç1karılır. Anlatılan örnekler, yalnızca terimlerinin verimlilik derecesinde farkl1laşır. Voltmetre okumaları, bilimsel olarak pek çok önemli tümcenin çıkarımını, belki de bir yağmur damlasının davranıșını yaptığından daha çok haklı gösterecektir: Konușma hareketleri, belli bir yönde, böyle çıkarımları bașka insanın bedensel hareketlerini yaptığından daha çok haklı gösterecektir (Carnap, 1959: 195-6).

Böylece bir gülüs,, bir korkulu bakıș, bir değiniș ya da bir haykırıș, bu çeşitli fiziksel hareketlerin yararlı çıkarımlar sağladığı ölçüde farklılıklar olabilmesine karșın, bir ölçüm ibresinin hareketinden "ilkece” farklı olarak "yorumlanmıș” olmaz.

Doğal davranışçı Petersen bașka insanları betimleyecek, onları gözlemleyecek ve salt fiziksel betimlemeler açısından düșünecektir. Onun, bunları zihinsel betimlemelere çevirebildiğini varsaymalıyı, yoksa kavramlar konusunda çok yetersiz kalacaktır. Ancak Petersen, eğer isteseydi, 
o çevirimleri yapmaktan sakınabilirdi. O, fiziksel betimlemeleri başka insanlara uygulama dıșında bir șey yapmayarak haftaları arka arkaya bulabilirdi.

Petersen'i fiziksel çevresini yalnızca iki boyutlu olarak gören biriyle karşılaștırabiliriz. O kimse, onun üç boyutlu olduğunu sanır. Derinlik boyutundaki bedenlerin özelliklerini onların yatay ve dikey özelliklerinden (biçim, boy, renk, hareket) çıkarabilir. Bir yelkenli teknenin kendisinden veya ona doğru uzaklaștığını bilirken, onu uzaklașıyor veya yaklașıyor olarak görmez. Bu gerçek nasıl görünebilir? Belki de o șeyin bir belirtisi, bu kișinin asla șöyle bir bağırma eğiliminde olmayıșı olacaktır: "Șu botun bize doğru ne kadar hızlı geldiğine bir bakın!” Yine bașkaları bu tarz konuștuğunda șașırmıș olabilir ve șu yönde karșı çıkmaya hazırlanabilir: “Onun yaklaștığını biliyorsun, ancak yaklaștığını görmüyorsun!”

Wittgenstein beyaz kâğıda siyah çizgilerle çizilmiș bir üçgenden șöyle söz eder:

Bu üçgen üçgen biçiminde bir delik, bir katı cisim, bir geometrik çizim olarak; tabanın üzerine dayanan, tepesinden asılı șey olarak; bir dağ, bir takoz, bir ok veya gösterge değneği, dik açının kısa kenara dayandığı kastedilen devrik bir nesne, bir yarı paralelkenar ve bașka çeșitli șeyler olarak görülebilir (Wittgenstein, 1953: 200).

O yolların hiçbiriyle o șeyi göremeyen birini düșünebiliriz. Belki de o kimse onu bir çukur, bir katı madde, yatay veya dikey olarak değil de düz bir yüzeydeki bir figür olarak görebilir. Yahut onu bu yolların her biriyle görmeye çalıșabilir ve bașarılı veya bașarısız olabilir. Șimdi bu kimsenin bir mimarın çizimine uygun bir yapı yapması gerektiğini varsayalım. Çizimin ilk parçası bir üçgendir. $\mathrm{O}$ șeyin bir boșluğu gösterdiğini bildiği hâlde, onu bir boșluk olarak göremez. Yapıyı da ona göre yapar.

$\mathrm{Bu}$ örnek, bizim doğal davranıșçı hakkındaki düşüncemiz için bir analoji sağlar. Sonuncusu, bir insanın yüzünü dostça veya öfkeli olarak göremez. (Belki o kimsenin onu bir yüz olarak göremediğini bile söylememiz gerekir.) Söylemin değișiminin öylece olduğunu göremez. O, bir yüzdeki değișimleri ancak üç boyuttaki fiziksel değișimler olarak görür.

Wittgenstein șuna değinir: " $\Upsilon \ddot{u ̈ z e ~ a i t ~ i f a d e l e r i n ~ t a n ı n m a s ı n ı ~ v e y a ~ y u ̈ z u ̈ n ~}$ ölçümlerini vermeye bağlı bulunmayan yüze ait ifadelerin betimlemelerini 
düşünün! Yine, birinin aynada kendi yüzüne bakmaksızın bir insanın yüzüne nasıl öykünebildiğini düșünün.” (Wittgenstein, I953: 285).

Çok doğal bir biçimde Petersen'e gelen bir yüze dair betimleme biçiminin ölçümler vermeye bağlı olduğunu düșleyelim. O, yüzleri ve onların söylemlerini, önceden de ifade ettiğimiz gibi, geometrik betimlemeler altında görür.

Benzer șeyler ișitsel dünya için de doğru olacaktır. Petersen insan konușmasını yüreklendirme, gözdă̆ı verme ya da yalvarma olarak değil de tonda, perdede ve sesteki değișme olarak ișitecektir. Belki de onun insanlar tarafından çıkarılan sesleri konuşma olarak ișitmeyeceğini, ancak o șeyin konușma olduğunu çıkaracağını söylemeliyiz. Mantıksal davranıșçılığa göre bir kișinin söylemleri veya "konușma hareketleri", bir voltmetrenin hareketlerinden ilkece farklı olarak yorumlanmaz. Petersen, belli akustik özellikleri olan söylemlerin bir kiși tarafından belli koșullarda yayıldığında, kișinin bir soru sorduğunun, birine yanıt verdiğinin veya bir șeyi ifade ettiğinin çıkarılabildiğini bilmek için yeterli genel bilgiye sahiptir. Ancak Petersen birinin konușmasını soru sorma, bir șeyi ifade etme, hatta herhangi bir șey söyleme olarak ișitmeyecektir. Onun insanlar hakkında bilgisiz olduğu söylenemez. Gerçekten, oldukça çok sayıdaki bilgiyi, yani geçiș sağlamak için kendisine olanak sağlamak amacryla yeterli kuramsal bilgiyi ona yüklüyoruz, ister tümevarımsal ister tümdengelimsel olsun, salt fiziksel betimlemelerden zihinsel betimlemelere pek çok bilgiyi. (Böyle bir bilginin olası olduğuna inanmak zorunda değiliz, ancak böyle bir bilgiyi, bu karșılaștırmanın amacı için varsaymamız gerekir.)

Petersen'in bizden adamakıllı farklı olduğu açıktır. İnsan davranıșının salt fiziksel betimlemeleri bize doğal gelmez. Ben bile böylesi betimlemeler yapamam. Buradaki durum bizim fiziksel dünyayı nasıl algıladığımız problemiyle benzerdir. Kimi filozoflar fiziksel nesneleri (cisimleri) görmediğimizi, en azından dolaysızca görmediğimizi, dolaysızca gördügüumüz șeylerin renkler (renk düzlemleri) olduğunu ileri sürdüler. Ancak gerçek șu ki, eğer oturduğum odayı size cisimlerin ("sandalye, lamba, duvar, kilim”) adlarını kullanarak değil de yalnızca renk düzlemleri arasındaki uzamsal ilișkiler açısından onu betimlemek isteseydim, bunu yapamazdım. Bu, gerçekten gördüğüm veya dolaysızca gördüğüm șeylerin renkler olup cisimler olmadığının yanlıs, olduğunu gösterir. $\mathrm{O}$ filozofların, gördüğ̈̈müz șeylerin 
betiminin en temel biçimi olduğunu sandıkları șey, aslında benim (genel anlamıyla insanların) bile kullanamadığım bir betimleme biçimidir. Bir yürüyüșe çıktığımda, belki de çalıșma ve çabayla, yalnızca ağaç, ev ve araç gibi beni fiziksel olarak çevreleyen șeyleri değil, aynı zamanda kesișen renk düzlemlerini de görebilirim. Ancak șimdi girișimde bulunmak, bunun benim fiziksel dünyayı normal algılayıs, tarzımdan nasıl uzak olduğumu anlamaktir.

Benzer durum, insan görünümü ve davranıșının salt fiziksel betimi hakkında gerçeği ele alır. Birisinin zihinsel yüklemler (“öfkeli, somurtkan, neșeli, çekingen”) açısından nasıl göründügünü betimleyebilirim. Ancak uzamsal ifadelerin geometrik betimlemelerini yapamam. Bu yüzden, benim için (genel anlamıyla insanlar için) geometrik betimlemelerin, uzamsal ifadeler hakkındaki zihinsel betimlemelerimin bir șeyden bir șeye çevrilebildiği temel betimleme biçimi olduğu yanlıștır. İșitsel dünyada ise bir koșutluk vardır. Sydney Shoemaker șunları söyler:

Biz konușan, bu tarz seslerin geçmiște söylendiği koșulları bilen bir kișiye yalnızca belli tümevarımsal çıkarımlar yaptığımız sesler çıkaran biri değil, aynı zamanda bir șey söyleyen biri gözüyle bakarız. Basitçe bir barometre okumasının anlama sahip olduğu anlamında, yani bir șeyin olmuș olduğunu, olmakta olduğunu veya olmak hakkında olduğunu göstererek değil, aynı zamanda onun neyi kastettiğini açıklayarak da o kimsenin söylediği șeyleri anlama sabip sayarız. Bunu, hakkımızdaki bir inanç, bizim kullandığımız sözcükleri kullanan kișilerin bizim onlarla kastettiğimiz șeyi kastettikleri yönündeki inanç diye betimlemek yanıltıcı olur. Aksine o șey, konușan bir kimseye karșılık verdiğimiz tutumun, tarzın bir konusudur... Eğer bu tutum inanca dair bir șey olsaydı, bu inancın nedenlerini araștırırdık. Ancak bu, tam da yapmadiğımız șeydir. Bu, bașkalarının söylediklerini tanıklık diye sayma konusunda bizi haklı gösteren șeye dair sorunun ortaya çıkmadığı bu tutumun açıklamasının parçasıdır. "Onun 'Geleceğim' sözlerini söylediğini işittim ve geleceğini söylediğini bundan çıkardım” demek yerine "Geleceğini söylediğini ișittim” deriz (Shoemaker, 1963: 249-50).

İnsanların eylemini nadir olarak salt fiziksel terimlerle algılarız. Birinin konușmasını tutkulu olarak ve hareketlerini de ürkütücü olarak algılarız. İnsanları (tez canlı, üzgün, sevecen gibi) zihinsel betimlemeler altında algılarız ve öylece karșılık veririz. Bu algı biçimi bizim için doğalken, salt 
bir fiziksel betimleme altındaki algı için değildir. Belki bunun nasıl öyle olduğunu anlamayız, ancak bu, onun öyle olduğunu tanımamıza engel olmamalidir.

Mantıksal davranışçılık, artık ı93olarda olduğu kadar revaçtadır. Ancak bir öğreti, yanlıș nedenlerden dolayı çekiciliğini yitirebilir. Zihinsel betimlemelerin çevirimlerini salt fiziksel betimlemelere tüm ayrıntısıyla sağlamanın olanaksız olduğu șimdi büyük ölçüde kabul edilir. Kimi filozoflar bunun, olağan dildeki zihinsel betimlemelerin belirsiz olması ve kesin olmaması, ne tam böyle ne de tam șöyle olması nedeniyle olduğunu düșünebilirler. $O$ filozoflar, olağan zihinsel betimlemelerin belirli bir anlama sahip olduğu kadarıyla, bunun fiziksel terimlerle çözümleme yoluyla açıklanabileceğini düșünebilirler. Onlar, mantıksal davranışçılığın tam anlamıyla doğru olmasa da (çünkü hiçbir șey tam olarak doğru değildir), yaklaşık olarak doğru olduğuna inanabilirler.

Doğrusu, bununla birlikte, mantıksal davranıșçılık temelde yanlıș bir görüștür. Bu, tıpkı bizim temel fiziksel dünya algımızın renkli düzlemlere dair olduğu düșüncesi kadar yanıș ve ona benzer tarzdadır. Birlikte çalıșıp sohbet ettiğimiz ve daha sonra zihinsel betimlemeler çıkardığımız insanları her șeyden önce salt fiziksel betimlemeler altında algılamayız. Biz $\mathrm{Pe}-$ tersen'den șu iki yolla ayrılırız:

İlk olarak, zihinsel betimlemeler altında insanlara dair algımız, bu betimlemelerin farklı bir tür betimlemelere dayanmadığı anlamında dolaysızdır. $\mathrm{Bu}$, somurtkan veya sevinçli biri hakkındaki algımın onun koșullarına dair bilgime dayandığını yadsımak değildir. Ancak amaç, bu bilginin verilmesiyle, onun yüzündeki sevinci ya da onun duruşundaki somurtkanlığı görüyor olmamdır. Bu șeyleri, gördügüm bașka bir șeyden çıkarmakta zorlanmiyorum.

İkinci olarak, pek çok parça için insan davranıșının salt fiziksel betimlemelerini veremeyiz, hatta kavrayamayız. Birine önemli bir bilgi taș1dığımı ve sizin de onun nasıl bir karșılık verdiğini bilmek istediğinizi varsayın. Tüm zihinsel terimlerden kaçınarak fiziksel (geometrik ve akustik) terimlerle size o șeyin bir betimini verdiğimi varsayın. (Elbette onun boșnut göründüğünü ya da sıkılgan konuștuğunu söyleme hakkım yok.) Benim betimlememi anlamayacaksınız - yani, onun nasıl bir karșılık verdiğini bilmeyeceksiniz! İstediğiniz bilgiyi bu betimlemeden, yalnızca renk düz- 
lemleri açısından odamın nasıl döșendiğini onun bir betiminden öğrenebilmenizden daha fazlasını türetemezsiniz.

Wittgenstein, bir tașın duygulara sahip olduğunu düșlemede zorluk çekmemize karşın, kıvrılan bir böceğe duyguları yüklemede bizim açımızdan hiçbir sıkıntı olmadığına değinir ve șunu ekler: "Bir ceset bize ağrıya tam anlamıyla ulașilamaz görünür. - Yașamaya karșı tutumumuz ölüme karșı olanla aynı değildir. Bütün tepkilerimiz farklıdır.” (Wittgenstein, I953: par. 284).

Tepkiler konusundaki bu ayrımın bir kimseye doğal olarak gelmediğini varsayın. Eğer onun bilgisi büyük veya bizimkinden büyükse, bu kișinin yanlış olduğunu söyleyemeyiz. O kimse ağrı, bilinç veya herhangi zihinsel yüklemlerin kavramlarına bizim sahip olmamızla olmamıla ayn tarzda sahip olmaz. Ben onun bir kiși kavramına sahip olmadığını, en azından bizim sahip olduğumuz tarzda sahip olmadığını söylemeye eğilimliyim.

İnsanların açıklamaları, hareketleri ve söylemlerine karșı tepkilerimiz, yani doğal tutumlarımız, zihinsel kavramlarımızın bir boyutunu olușturur. Bu boyut, algılama, ona karşıllk verme yoluyla özneye katılır.

Mantıksal davranıșçılığın iki eleștirisinden birisi, bir kiși tarafından birine zihinsel yüklemlerin yüklenmesiyle, diğeri de birinin bașka kișilere zihinsel yüklemleri yüklemesiyle ilgilidir. Yapılan ilk eleștiri, șimdiye kadar çağdaș filozoflara çok tanıdık gelir, yani bir insanın kendi yönelim, düșünce ve duyguları hakkındaki ifadeleri (genellikle) onun kendi davranışını gözlemlemesine dayanmaz. Böylelikle davranışçılığın basit geniş zaman bildiren birinci tekil kiși konusundaki psikolojik tümcelerin "içerik"iyle ilgili düșüncesi yanlıștır.

İkinci eleștiri ise daha az tanıdık ve belki de tutulması daha güç olanıdır. O, davranışçılı̆̆ın ikinci ve üçüncü (tekil ve çoğul) kiși psikolojik tümcelerin "içerik"iyle ilgili açıklamasına karşı çıkıștır. Davranışçı görüșe göre, bu tümceler salt fiziksel betimlemeler içeren tümcelere çevrilebilir ve bu betimleme biçiminin zihinsel betimleme biçimlerinden daha köklü olduğu anlașılır. Doğal bir davranıșçıyı, bașka insanları salt fiziksel betimlemeler altında algılayan ve uygun zihinsel betimlemeler türeten birini düşlemeye çalıștık. Doğal davranıșçı, korkmuş veya ağrılı olduklarını bil- 
diği hâlde, insanları korkmuş veya ăgrılı olarak algılamaz. Zihinsel kavramlar onun insanlara ilișkin algısında içerilmez. O kimse bir yüzü șașırmıș veya korkulu olarak görememișse, o hâlde onun yüze ait ifadelere karș1 tepkilerinin bizimkiyle aynı olmadığı açıktır. Onun doğal tutumları mantıksal davranıșçılığın kuramsal bakıș açısına uymaması nedeniyle, normal olandan ayrı olmasındaki tuhaflık, davranısçılı̆̆ın, zihinsel kavramların gerçekten kullanıldığı doğru bir açıklama tarzı sunmadığını gösterir. Bu betimleme biçimini insanlara bile uygulayamadığımız için, salt fiziksel betimlemelerin daha köklü olduğu yönündeki davranıșçı düșünce, hepten yanlıștır. Bu nedenle davranışçlık, onları hem kendimize uygularken hem de bașkalarına uygularken, zihinsel kavramların bir yanlıș anlayıșına sahip olur.

\section{Kaynaklar}

Carnap, R. (1953). Psychology in Physical Language. Logical Positivism (ed. A. J. Ayer). Glencoe, Illinois.

Malcolm, N. (1964). Behaviorism as a Philosophy of Psychology. Behaviorism and Phenomenology (ed. T. W. Wann). Chicago.

Shoemaker, S. (1963). Self-Knowledge and Self-Identity. Ithaca, New York.

Skinner, B. F. (1953). Science and Human Behaviour. New York.

Wittgenstein, L. (1953). Philosophical Investigations. New York.

Öz: Makale yalnızca 'Mantıksal Davranışçılık' denen öğretiyi ele alıyor. Bu durum, I930 ve I940lı yıllarda pek rağbet görmemesine rağmen, daima psikolojik kavramlarla kafası karıșmıș olan, o kavramları nasıl öğreneceğimiz hakkında bir anlatım olarak iç gözleme bașvurmanın değersizliğinin ayırdında olan ve de zihni beyinle özdeșleștirmeye eğilimi olmayan bir kimse için ilgi uyandıran bir çekiciliğe sahip olacaktır. Bu incelemede tartışılan davranışçılık ve indirgemeciliğin elbette bașka biçimleri de vardır. Carnap'ın görüșlerinden hareketle, çalıșma eğer okuyucuyu zihin felsefesinin kușkusuz en önemli figürü olan Wittgenstein'ın eserlerine sürüklerse, amacına hizmet etmiș olur. Bununla birlikte, onun Felsefî Soruș- 
turmalar veya Zettel adlı eserinin yansıma ve gözlemlerinin, bir șekilde bașka kurama yol açacağı beklenmemelidir. Onun metaforunu kullanmak için, uygun felsefî çalıșmalar sadece anlayışımızdaki dügümleri çözer.

Anahtar Kelimeler: Mantıksal davranışçlık, Wittgenstein, Carnap, bakıșımsızlık, tutum ve davranıșlar. 